\title{
CRYSTAL STRUCTURES OF COPPER(II) AND ZINC(II) COMPLEXES DERIVED FROM 3-(2-PYRIDYL)PYRAZOLE
}

\author{
X.B. Liu, D.H. Huan, G.H. Cui, L.H. Han \\ College of Chemical Engineering, Hebei United University, Tangshan, Hebei Province, P. R. China \\ E-mail: tscghua@126.com (G.H.Cui)
}

Received June, 24, 2014

Two dinuclear complexes $\left[\mathrm{Zn}(\mu-\mathrm{L})\left(\mathrm{NO}_{3}\right)\left(\mathrm{H}_{2} \mathrm{O}\right)\right]_{2}(\mathbf{1})$ and $\left[\mathrm{Cu}_{2}(\mu-\mathrm{L})_{2}(\mathrm{HL})_{2}\right]\left(\mathrm{NO}_{3}\right)_{2}\left(\mathrm{C}_{12} \mathrm{H}_{8} \mathrm{Br}_{2}\right)_{0.5}$. $\cdot \mathrm{H}_{2} \mathrm{O}$ (2), ( $\mathrm{HL}=3$-(2-pyridyl)pyrazole, $\mathrm{C}_{12} \mathrm{H}_{8} \mathrm{Br}_{2}=4,4$ '-dibromobiphenyl) are synthesized under hydrothermal conditions and characterized by elemental analysis and X-ray single crystal diffraction. Crystal data for 1: triclinic, $P \overline{1}, a=8.8478(7) \AA, \quad b=15.0550(11) \AA$, $c=16.4310(12) \AA, \alpha=107.588(4)^{\circ}, \beta=112.498(3)^{\circ}, \gamma=115.595(3)^{\circ}, V=2099.8(9) \AA^{3}, Z=2$; for 2: triclinic, $P \overline{1}, a=7.2870(15) \AA, b=8.6840(17) \AA, c=9.3290(19) \AA, \alpha=107.588(4)^{\circ}$, $\beta=112.498(3)^{\circ}, \gamma=115.595(3)^{\circ}, V=528.77(18) \AA^{3}, Z=1$. Complex 1 and 2 are both dinuclear structures which are further packed into a $1 \mathrm{D}$ supramolecular chain and a $3 \mathrm{D}$ supramolecular framework via weak $\mathrm{C}-\mathrm{H} \cdots \mathrm{O}$ hydrogen bond interactions respectively.

DOI: $10.15372 / J S C 20150615$

K e y w o r d s: copper(II), crystal structure, 3-(2-pyridyl)pyrazole, zinc(II).

The rational design and synthesis of metal-organic complexes have been attracting great interest in coordination and supramolecular chemistry because of their intricate structures and fascinating topologies as well as their potential applications as new functional materials [ $1-4]$. Intermolecular interactions, especially hydrogen bonding, have proven to be an interesting tool in supramolecular syntheses and manipulation of the final architecture [5]. Nevertheless, it is still tremendously difficult and long-term challenge to construct target complexes with expected structures and properties due to the fact that many other factors, including organic ligands, temperatures, $\mathrm{pH}$ values, template, solvents, counter ions and crystallization methods, play significant roles in the self-assembly process [6-9]. The selection of appropriate organic ligands is very pivotal for obtaining target complexes with intriguing structures and properties [10,11]. Among these ligands, the 3-(2-pyridyl)pyrazole ligand (HL) is a good choice to fabricate various metal-organic complexes due to the following characters. Firstly, it shows an excellent coordination ability with several coordination modes and has been extensively used as a bidentate ligand, quite similar to 2,2'-bipyridyl or 1,10-phenanthroline, and the complexes exhibit various applications in the areas of catalysis, photophysics, information processing, and host-guest chemistry [12]. Moreover, it acts as a tridentate chelate-bridging ligand after deprotonation of the pyrazolyl $\mathrm{NH}$ group and further coordination of the pyrazolyl $\mathrm{N}$ atom to another metal ion [ 13]. Secondly, this type of ligands contains both pyrazolyl ring and larger conjugated $\pi$ system, capable of participating in the hydrogen bonding and $\pi-\pi$ stacking interactions, especially in the aspect of packing multinuclear discrete subunits into a high-dimensional supramolecular framework [ 14 ]. In the last decades, the combination of HL and metal salts has attracted great interest of researchers [ 15-17 ]. In this work, we report the synthesis and crystal structures of $\mathrm{Cu}(\mathrm{II})$

(C) Liu X.B., Huan D.H., Cui G.H., Han L.H., 2015 
and $\mathrm{Zn}(\mathrm{II})$ complexes based on the 3-(2-pyridyl)pyrazole ligand: $\left[\mathrm{Zn}(\mu-\mathrm{L}) \mathrm{NO}_{3}\left(\mathrm{H}_{2} \mathrm{O}\right)\right]_{2}(\mathbf{1})$ and $\left[\mathrm{Cu}_{2}(\mu-\right.$ $\left.\mathrm{L})_{2}(\mathrm{HL})_{2}\right]\left(\mathrm{NO}_{3}\right)_{2}\left(\mathrm{C}_{12} \mathrm{H}_{8} \mathrm{Br}_{2}\right)_{0.5} \cdot \mathrm{H}_{2} \mathrm{O}(2)$.

Experimental. Materials and physical measurements. All the solvents and reagents for the synthesis were commercially available and used as received. HL was synthesized according to the literature method [18 ]. Elemental analyses were taken on a Perkin-Elmer 240C analyzer.

Synthesis of $\left[\mathrm{Zn}(\mu-\mathrm{L}) \mathrm{NO}_{3}\left(\mathbf{H}_{2} \mathbf{O}\right)\right]_{2}$ (1). A mixture of $\mathrm{HL}(0.2 \mathrm{mmol}, 29 \mathrm{mg}), \mathrm{Zn}\left(\mathrm{NO}_{3}\right)_{2} \cdot 6 \mathrm{H}_{2} \mathrm{O}$ $(0.2 \mathrm{mmol}, 59 \mathrm{mg})$, ethanol $(1 \mathrm{ml})$, and $\mathrm{H}_{2} \mathrm{O}(10 \mathrm{ml})$ was stirred for $0.5 \mathrm{~h}$ in air, then the resulting mixture was transferred in a Teflon-lined stainless reactor and heated to $140{ }^{\circ} \mathrm{C}$ for 3 days under autogenous pressure and cooled to room temperature at a rate of $10^{\circ} \mathrm{C} / \mathrm{h}$. Consequently, the colorless blockshaped crystals suitable for X-ray single crystal diffraction were obtained with a yield of $36.7 \%$ (based on $\left.\mathrm{Zn}\left(\mathrm{NO}_{3}\right)_{2} \cdot 6 \mathrm{H}_{2} \mathrm{O}\right)$. Anal. calcd. for $\mathrm{C}_{16} \mathrm{H}_{16} \mathrm{Zn}_{2} \mathrm{~N}_{8} \mathrm{O}_{8}\left(M_{\mathrm{r}}=579.11\right)(\%)$ : C 33.18, H 2.78, $\mathrm{N}$ 19.35. Found (\%): C 32.97, H 2.62, N 19.11.

Synthesis of $\left[\mathbf{C u}_{2}(\mu-\mathrm{L})_{2}(\mathbf{H L})_{2}\right]\left(\mathbf{N O}_{3}\right)_{2}\left(\mathbf{C}_{12} \mathbf{H}_{8} \mathrm{Br}_{2}\right)_{0.5} \cdot \mathbf{H}_{2} \mathbf{O}$ (2). HL (0.2 mmol, $\left.29 \mathrm{mg}\right), \mathrm{Cu}\left(\mathrm{NO}_{3}\right)_{2}$. $\cdot 3 \mathrm{H}_{2} \mathrm{O}(0.2 \mathrm{mmol}, 48 \mathrm{mg}), 4,4^{\prime}$-dibromobiphenyl $(0.01 \mathrm{mmol}, 31 \mathrm{mg})$, ethanol $(3 \mathrm{ml})$ were added to $12 \mathrm{ml} \mathrm{H}_{2} \mathrm{O}$, subsequently, the mixture was placed in a Teflon-lined stainless reactor and heated to $140{ }^{\circ} \mathrm{C}$ for 3 days under autogenous pressure. Finally, the blue block-shaped crystals suitable for X-ray single crystal diffraction were obtained with a yield of $32.7 \%$ (based on $\mathrm{Cu}\left(\mathrm{NO}_{3}\right)_{2} \cdot 3 \mathrm{H}_{2} \mathrm{O}$ ). Anal. calcd. for $\mathrm{C}_{38} \mathrm{H}_{30} \mathrm{BrCu}_{2} \mathrm{~N}_{14} \mathrm{O}_{7}\left(M_{\mathrm{r}}=1001.75\right)(\%)$ : C 45.56, H 3.02, N 19.58. Found (\%): C 45.33, H 3.28, N 19.29.

$\mathrm{Tab} 1 \mathrm{e} 1$

Crystal data and structure refinements for complexes $\mathbf{1}$ and $\mathbf{2}$

\begin{tabular}{|c|c|c|}
\hline Complex & 1 & 2 \\
\hline Empirical formula & $\mathrm{C}_{16} \mathrm{H}_{16} \mathrm{Zn}_{2} \mathrm{~N}_{8} \mathrm{O}_{8}$ & $\mathrm{C}_{38} \mathrm{H}_{30} \mathrm{BrCu}_{2} \mathrm{~N}_{14} \mathrm{O}_{7}$ \\
\hline Formula weight & 579.11 & 1001.75 \\
\hline$T, \mathrm{~K}$ & $296(2)$ & $296(2)$ \\
\hline Wavelength, $\AA$ & 0.71073 & 0.71073 \\
\hline Crystal system & Triclinic & Triclinic \\
\hline Space group & $P \overline{1}$ & $P \overline{1}$ \\
\hline Unit cell dimensions: & & \\
\hline$a, b, c, \AA$ & $7.28710(15), 8.6840(17), 9.3290(19)$ & 13.381(3), 14.735(4), 15.440(4) \\
\hline$\alpha, \beta, \gamma$, deg. & $112.73(3), 92.48(3), 101.52(3)$ & $107.588(4), 112.498(3), 115.595(3)$ \\
\hline$V, \AA^{3}$ & $528.77(18)$ & 2099.8(9) \\
\hline$Z$ & 1 & 2 \\
\hline$D_{\text {calc }}, \mathrm{g} / \mathrm{cm}^{3}$ & 1.819 & 1.584 \\
\hline Absorption coefficient, $\mathrm{mm}^{-1}$ & 2.332 & 2.030 \\
\hline$F(000)$ & 292 & 1010 \\
\hline Crystal size, $\mathrm{mm}$ & $0.24 \times 0.23 \times 0.19$ & $0.20 \times 0.16 \times 0.15$ \\
\hline$\theta$ range, deg. & $3.41-25.02$ & $1.72-25.68$ \\
\hline$h, k, l$ range & $-8 \leq h \leq 8,-10 \leq k \leq 10,-11 \leq l \leq 11$ & $-16 \leq h \leq 16,-17 \leq k \leq 16,-13 \leq l \leq 18$ \\
\hline Reflections collected / unique & $4453 / 1853$ & $11047 / 7790$ \\
\hline Max. and min. transmission & 0.6892 and 0.6028 & 0.8068 and 0.6321 \\
\hline Refinement method & Full-matrix least-squares on $F^{2}$ & Full-matrix least-squares on $F^{2}$ \\
\hline Data / restraints / parameters & $1853 / 3 / 154$ & $7790 / 0 / 550$ \\
\hline GOOF on $F^{2}$ & 1.033 & 1.010 \\
\hline Final $R$ indices $[I>2 \sigma(I)]$ & $R 1=0.1117, w R 2=0.2242$ & $R 1=0.0733, w R 2=0.2069$ \\
\hline$R$ indices (all data) & $R 1=0.2029, w R 2=0.2703$ & $R 1=0.1295, w R 2=0.2323$ \\
\hline Residual peak and hole., e $/ \AA^{3}$ & 0.853 and -0.717 & 0.690 and -0.530 \\
\hline
\end{tabular}


Selected bond lengths $(\AA)$ and angles (deg.) for complexes $\mathbf{1}$ and $\mathbf{2}$

\begin{tabular}{|c|c|c|c|c|c|}
\hline Parameter & Value & Parameter & Value & Parameter & Value \\
\hline \multicolumn{2}{|c|}{$\left[\mathrm{Zn}(\mu-\mathrm{L})\left(\mathrm{NO}_{3}\right)\left(\mathrm{H}_{2} \mathrm{O}\right)\right]_{2}(\mathbf{1})$} & \multicolumn{4}{|c|}{$\left[\mathrm{Cu}_{2}(\mu-\mathrm{L})_{2}(\mathrm{HL})_{2}\right]\left(\mathrm{NO}_{3}\right)_{2}\left(\mathrm{C}_{12} \mathrm{H}_{8} \mathrm{Br}_{2}\right)_{0.5} \cdot \mathrm{H}_{2} \mathrm{O}(\mathbf{2})$} \\
\hline $\mathrm{Zn} 1-\mathrm{N} 1$ & $2.029(10)$ & $\mathrm{Cu} 1-\mathrm{N} 2$ & $1.962(5)$ & $\mathrm{Cu} 2-\mathrm{N} 8$ & $1.969(6)$ \\
\hline $\mathrm{Zn} 1-\mathrm{O} 1 \mathrm{~W}$ & $2.128(9)$ & $\mathrm{Cu} 1-\mathrm{N} 9$ & $1.966(6)$ & $\mathrm{Cu} 2-\mathrm{N} 3$ & $1.970(6)$ \\
\hline $\mathrm{Zn} 1-\mathrm{O} 1$ & $2.263(9)$ & $\mathrm{Cu} 1-\mathrm{N} 5$ & $2.036(5)$ & $\mathrm{Cu} 2-\mathrm{N} 11$ & $2.001(6)$ \\
\hline $\mathrm{N} 1-\mathrm{Zn} 1-\mathrm{N} 2 \mathrm{~A}$ & $101.3(4)$ & $\mathrm{Cu} 1-\mathrm{N} 1$ & $2.045(6)$ & $\mathrm{Cu} 2-\mathrm{N} 7$ & $2.060(6)$ \\
\hline $\mathrm{N} 1-\mathrm{Zn} 1-\mathrm{O} 1 \mathrm{~W}$ & $96(4)$ & $\mathrm{Cu} 1-\mathrm{N} 4$ & $2.310(6)$ & $\mathrm{Cu} 2-\mathrm{N} 10$ & $2.315(7)$ \\
\hline $\mathrm{N} 2 \mathrm{~A}-\mathrm{Zn} 1-\mathrm{O} 1 \mathrm{~W}$ & $108.1(4)$ & $\mathrm{N} 2-\mathrm{Cu} 1-\mathrm{N} 9$ & $95.2(2)$ & $\mathrm{N} 8-\mathrm{Cu} 2-\mathrm{N} 3$ & $96.5(2)$ \\
\hline $\mathrm{N} 1-\mathrm{Zn} 1-\mathrm{N} 3 \mathrm{~A}$ & $174.5(4)$ & $\mathrm{N} 9-\mathrm{Cu} 1-\mathrm{N} 5$ & $163.8(2)$ & $\mathrm{N} 8-\mathrm{Cu} 2-\mathrm{N} 11$ & $172.9(2)$ \\
\hline $\mathrm{N} 2 \mathrm{~A}-\mathrm{Zn} 1-\mathrm{N} 3 \mathrm{~A}$ & $79.2(4)$ & $\mathrm{N} 9-\mathrm{Cu} 1-\mathrm{N} 5$ & $95.4(2)$ & $\mathrm{N} 3-\mathrm{Cu} 2-\mathrm{N} 11$ & $90.6(2)$ \\
\hline $\mathrm{Zn} 1-\mathrm{N} 2 \mathrm{~A}$ & $2.057(10)$ & $\mathrm{N} 2-\mathrm{Cu} 1-\mathrm{N} 1$ & $81.1(2)$ & $\mathrm{N} 8-\mathrm{Cu} 2-\mathrm{N} 7$ & $80.6(2)$ \\
\hline $\mathrm{Zn} 1-\mathrm{N} 3 \mathrm{~A}$ & $2.145(10)$ & $\mathrm{N} 9-\mathrm{Cu} 1-\mathrm{N} 1$ & $155.3(2)$ & $\mathrm{N} 3-\mathrm{Cu} 2-\mathrm{N} 7$ & $168.1(2)$ \\
\hline $\mathrm{O} 1 \mathrm{~W}-\mathrm{Zn} 1-\mathrm{O} 1$ & $92.2(3)$ & $\mathrm{N} 5-\mathrm{Cu} 1-\mathrm{N} 1$ & $94.1(2)$ & $\mathrm{N} 11-\mathrm{Cu} 2-\mathrm{N} 10$ & $92.4(2)$ \\
\hline $\mathrm{N} 3 \mathrm{~A}-\mathrm{Zn} 1-\mathrm{O} 1$ & $89.8(4)$ & $\mathrm{N} 2-\mathrm{Cu} 1-\mathrm{N} 4$ & $89.7(2)$ & $\mathrm{N} 8-\mathrm{Cu} 2-\mathrm{N} 10$ & $104.1(2)$ \\
\hline $\mathrm{O} 1 \mathrm{~W}-\mathrm{Zn} 1-\mathrm{N} 3 \mathrm{~A}$ & $89.0(4)$ & $\mathrm{N} 9-\mathrm{Cu} 1-\mathrm{N} 4$ & $110.5(2)$ & $\mathrm{N} 3-\mathrm{Cu} 2-\mathrm{N} 10$ & $97.6(2)$ \\
\hline $\mathrm{N} 1-\mathrm{Zn} 1-\mathrm{O} 1$ & $87.7(4)$ & $\mathrm{N} 5-\mathrm{Cu} 1-\mathrm{N} 4$ & $75.1(2)$ & $\mathrm{N} 11-\mathrm{Cu} 2-\mathrm{N} 10$ & $75.1(2)$ \\
\hline $\mathrm{N} 2 \mathrm{~A}-\mathrm{Zn} 1-\mathrm{O} 1$ & $156.5(4)$ & $\mathrm{N} 1-\mathrm{Cu} 1-\mathrm{N} 4$ & $94.0(2)$ & $\mathrm{N} 7-\mathrm{Cu} 2-\mathrm{N} 10$ & $94.2(2)$ \\
\hline
\end{tabular}

Symmetry code for 1 : A: $-x,-y+1,-z+1$.

Syntheses and general methods. Complexes 1 and 2 were prepared by the reaction of copper(II)/zinc(II) salt, HL ligand in the 1:1 molar ratio in the water/alcohol system. The results of elemental analyses for the two complexes were in good agreement with the theoretical requirements of their compositions (X-ray analysis results). 4,4'-dibromobiphenyl was added into the reaction system due to a mistake operation; it was involved in complex 2. However, without it, the reaction of HL and $\mathrm{Cu}\left(\mathrm{NO}_{3}\right)_{2} \cdot 3 \mathrm{H}_{2} \mathrm{O}$ in the same situation did not afford suitable crystals of $2 ; 4,4^{\prime}$-dibromobiphenyl is likely to further stabilize the complex 2 crystal packing via a supramolecular interaction.

X-ray crystallography. X-ray single crystal diffraction data for the title complexes were collected on a Bruker Smart $1000 \mathrm{CCD}$ diffractometer with graphite monochromated $\mathrm{Mo} K_{\alpha}$ radiation $(\lambda=0.71073 \AA)$ and $\omega-2 \theta$ scan mode at $296 \mathrm{~K}$. A semi-empirical absorption correction was applied using the SADABS program [19]. The structures were solved by direct methods using the SHELXS97 program [20 ] and refined using SHELXL-97 by the full-matrix least-squares fitting on $F^{2}$ [21]. All non-hydrogen atoms were refined anisotropically. In 2, one water molecule is disordered and the structure was refined by the SQUEEZE routine of the PLATON program [22 ]. Crystallographic data and experimental details for structural analyses of complexes $\mathbf{1}$ and $\mathbf{2}$ are summarized in Table 1. Selected bond lengths and angles are listed in Table 2. All $\mathrm{H}$ bonding geometries are given in Table 3 . CCDC 1044332-1044333 contains the supplementary crystallographic data. These data can be obtained from the Cambridge Crystallographic Data Centre, 12 Union Road, Cambridge CB2 1EZ, UK; Fax:+44-1223-336033; E-mail: deposit@ccdc.cam.ac.uk.

Results and discussion. Crystal structure of $\left[\mathrm{Zn}(\mu-\mathrm{L})\left(\mathrm{NO}_{3}\right)\left(\mathrm{H}_{2} \mathrm{O}\right)\right]_{2}(\mathbf{1})$. The X-ray single crystal diffraction analysis reveals that complex 1 crystallizes in the triclinic, $P \overline{1}$ space group. This zinc compound is isostructural to the copper counterpart $\left[\mathrm{Cu}(\mu-\mathrm{L})\left(\mathrm{NO}_{3}\right)\left(\mathrm{H}_{2} \mathrm{O}\right)\right]_{2}$ [23]. As shown in Fig. 1, $a$, the asymmetric unit of complex 1 consists of one independent $\mathrm{Zn}(\mathrm{II})$ ion, one deprotonated $\mathrm{L}$ ligand, one nitrate anion, and one coordinated water molecule. The $\mathrm{Zn}$ (II) ion is five-coordinated by three nitrogen atoms from two L ligands, one oxygen atom from the nitrate anion, and one oxygen atom from the coordinated water molecule to form a distorted square-pyramidal geometry with the 
Hydrogen bonding geometry $(\AA$, deg.) for complexes $\mathbf{1}$ and $\mathbf{2}$

\begin{tabular}{c|c|c|c|c}
\hline $\mathrm{D}-\mathrm{H} \cdots \mathrm{A}$ & $\mathrm{D}-\mathrm{H}$ & $\mathrm{H} \cdots \mathrm{A}$ & $\mathrm{D}-\mathrm{A}$ & $\mathrm{D}-\mathrm{H} \cdots \mathrm{A}$ \\
\hline \multicolumn{4}{c}{$\left.(\mu-\mathrm{L})\left(\mathrm{NO}_{3}\right)\left(\mathrm{H}_{2} \mathrm{O}\right)\right]_{2}(\mathbf{1})$} \\
$\mathrm{C} 33-\mathrm{H} 33 \cdots \mathrm{O} 2 \mathrm{~B}$ & 0.93 & 2.53 & 3.326 & 144 \\
{$\left[\mathrm{Cu}_{2}(\mu-\mathrm{L})_{2}(\mathrm{HL})_{2}\right]\left(\mathrm{NO}_{3}\right)_{2}\left(\mathrm{C}_{12} \mathrm{H}_{8} \mathrm{Br}_{2}\right)_{0.5} \cdot \mathrm{H}_{2} \mathrm{O}(\mathbf{2})$} \\
$\mathrm{C} 4-\mathrm{H} 4 \mathrm{~A} \cdots \mathrm{O} 1 \mathrm{~A}$ & 0.93 & 2.41 & 3.253 & 151 \\
$\mathrm{C} 7-\mathrm{H} 7 \cdots \mathrm{O} 2 \mathrm{~A}$ & 0.93 & 2.56 & 3.473 & 167 \\
$\mathrm{C} 16-\mathrm{H} 16 \cdots \mathrm{O} 2 \mathrm{~B}$ & 0.93 & 2.33 & 3.237 & 165 \\
$\mathrm{C} 34-\mathrm{H} 34 \cdots \mathrm{O} 2 \mathrm{C}$ & 0.93 & 2.60 & 3.510 & 166
\end{tabular}

Symmetry code: for 1 : B: $-x,-y+2,-z+1$.

Symmetry codes: for 2 : A: $-x+1,-y+1,-z+1, \mathrm{~B}:-x,-y+1$, $-z+1, \mathrm{C}: x, y, z-1$.

value $\tau_{5}=0.3\left(\tau_{5}=(\beta-\alpha) / 60 ; \alpha, \beta\right.$ are the two largest of the basic angles, $\tau_{5}=1$ for an ideal trigonal bipyramid, and $\tau_{5}=0$ for an ideal square pyramid) [24]. The three nitrogen atoms of two different $\mathrm{L}$ ligands (one pyridine $\mathrm{N}$ and two pyrazole $\mathrm{N}$ ) and one oxygen atom of the nitrate anion contribute to the basal plane at $\mathrm{Zn}$. The apical position is occupied by one oxygen atom the coordinated water molecule. Each $\mathrm{Zn}$ atom is displaced by $0.2831 \AA$ from the mean basal plane toward $\mathrm{O} 1 \mathrm{~W}$. The $\mathrm{Zn}-\mathrm{N}$ bond lengths vary from $2.029(10) \AA$ to $2.145(10) \AA$, and the $\mathrm{Zn}-\mathrm{O}$ bond distances are 2.263(8) $\AA$ (Zn1-O1) and 2.128(9) $\AA$ (Zn1-O1W), which are both within acceptable ranges [25, 26 ]. In complex $1, \mathrm{~L}$ acts as a terdentate chelating/bridging ligand via the deprotonation of the pyrazole NH group.

Two such asymmetric units are connected to construct a six-membered ring containing two $\mathrm{Zn}$ (II) ions and two L ligands $(\mathrm{Zn} 1 \cdots \mathrm{Zn} 1 \mathrm{~A}=3.919 \AA$, symmetry code for $\mathrm{A}:-x,-y+1,-z+1)$. The molecules of 1 are linked by intermolecular $\mathrm{C} 33-\mathrm{H} 33 \cdots \mathrm{O} 2 \mathrm{~B}$ hydrogen bonds between $\mathrm{L}$ ligands and nitrate oxygen atoms $\left(\mathrm{H} 33 \cdots \mathrm{O} 2 \mathrm{~B}=2.53 \AA, \mathrm{C} 33-\mathrm{H} 33 \cdots \mathrm{O} 2 \mathrm{~B}=144^{\circ}\right.$, symmetry code for $\left.\mathrm{B}:-x,-y+2,-z+1\right)$ to construct a 1D supramolecular chain (Fig. 1, $b$ ). The $\pi-\pi$ stacking interactions between the pyridine ring and the neighboring pyrazole ring from different $\mathrm{L}$ ligands $(\mathrm{Cg} 1 \cdots \mathrm{Cg} 2 \mathrm{~B}=3.739 \AA, \mathrm{Cg} 1$ : $\mathrm{N} 1-\mathrm{N} 2-\mathrm{C} 24-\mathrm{C} 20-\mathrm{C} 21, \mathrm{Cg} 2 \mathrm{~B}: \mathrm{N} 3-\mathrm{C} 18-\mathrm{C} 17-\mathrm{C} 33-\mathrm{C} 30-\mathrm{C} 25)$ further stabilize the crystal packing.

Crystal structure of $\left[\mathrm{Cu}_{2}(\mu-\mathrm{L})_{2}(\mathrm{HL})_{2}\right]\left(\mathrm{NO}_{3}\right)_{2}\left(\mathrm{C}_{12} \mathrm{H}_{8} \mathrm{Br}_{2}\right)_{0.5} \cdot \mathrm{H}_{2} \mathrm{O}$ (2). Complex 2 also crystallizes in the triclinic, $P \overline{1}$ space group. The asymmetric unit is made of two independent $\mathrm{Cu}$ atoms, two HL, and two deprotonated L ligands, two coordinated nitrate anions, and a half of lattice 4,4'-dibromobiphenyl molecule. As illustrated in Fig. 2, each of $\mathrm{Cu}$ atoms is coordinated by one oxygen atom from nitrate anions $(\mathrm{Cu} 1-\mathrm{O} 1=2.7784 \AA, \mathrm{Cu} 2-\mathrm{O} 4=2.7544 \AA)$, two nitrogen atoms from two distinct $\mathrm{L}$ ligands, and two nitrogen atoms from one $\mathrm{HL}$ ligand. The $\mathrm{Cu}-\mathrm{N}$ bond lengths range from 1.962(5) to $2.310(6) \AA$ (for $\mathrm{Cu} 1$ ) and 1.969(6) $\AA$ to 2.315(7) $\AA$ (for $\mathrm{Cu} 2$ ). Thus, the environment of $\mathrm{Cu}$ atoms is best described as a highly distorted octahedral geometry.

In 2 there also exists a binuclear six-membered ring furnished by two L ligands and two HL ligands, and the $\mathrm{Cu} 1 \cdots \mathrm{Cu} 2$ distance is $3.8909 \AA$. Each L1 ligand acts two types of roles, chelating one $\mathrm{Cu}$ (II) center and simultaneously bridging another one, showing a terdenate chelating-bridging mode. The distinction from $\mathbf{1}$ is that $\mathrm{L}$ and HL coexist in complex $\mathbf{2}$, and a neutral HL ligand coordinated to each $\mathrm{Cu}(\mathrm{II})$ center is in a chelating coordination mode. The 3D supramolecular framework is further constructed by weak $\mathrm{C}-\mathrm{H} \cdots \mathrm{O}$ hydrogen bonds (Table $3, \mathrm{H} \cdots \mathrm{A}: 2.33-2.60 \AA$; $\mathrm{D}-\mathrm{H} \cdots \mathrm{A}: 151-$ $\left.167^{\circ}\right)$. 

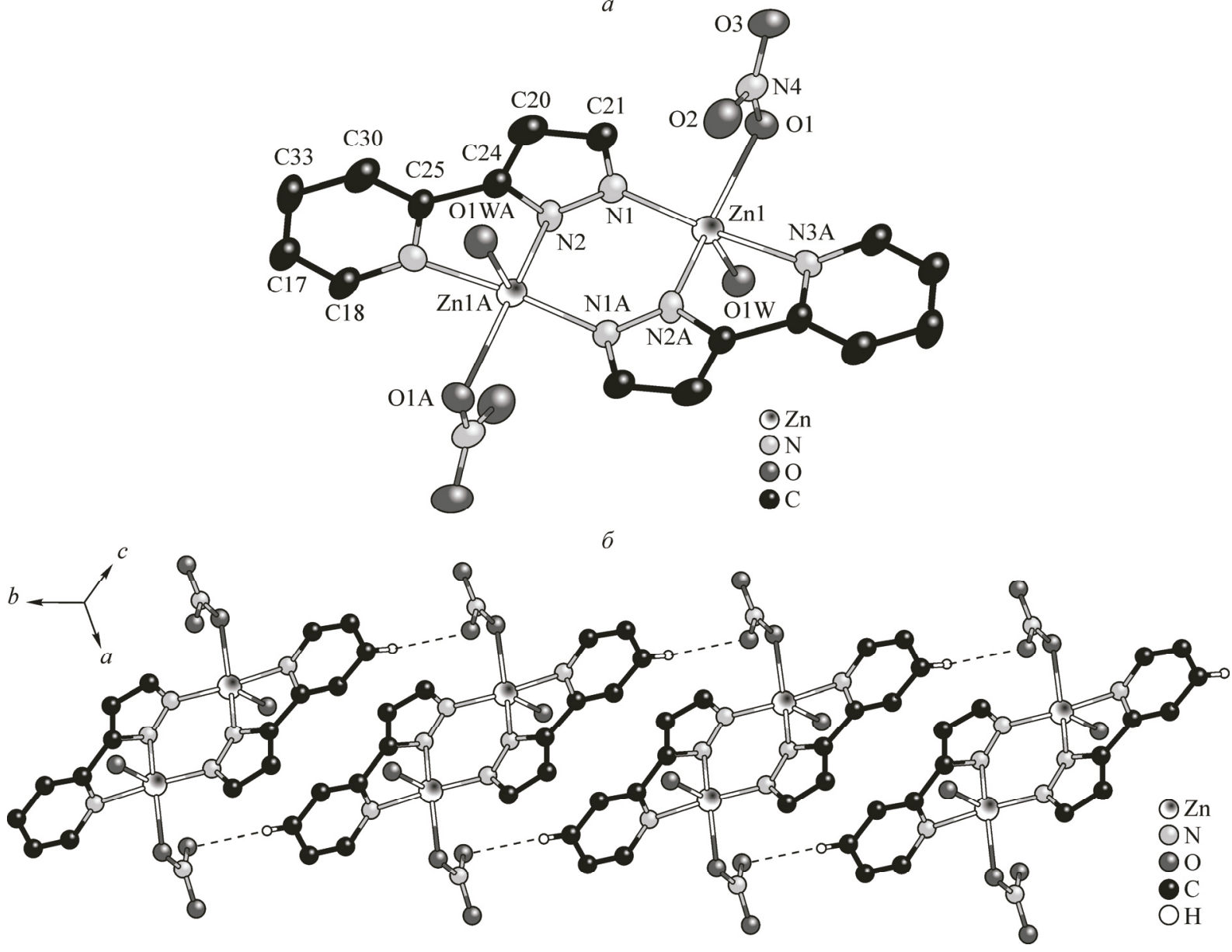

Fig. 1. Coordination environment of the $\mathrm{Zn}(\mathrm{II})$ ion in complex $\mathbf{1}(\mathrm{a})$. All the hydrogen atoms are omitted for clarity (symmetry code 1: $\mathrm{A}=-x,-y+1,-z+1$ ). 1D supramolecular chain constructed from $\mathrm{C}-\mathrm{H} \cdots \mathrm{O}$ hydrogen bond interactions in $\mathbf{1}(b)$

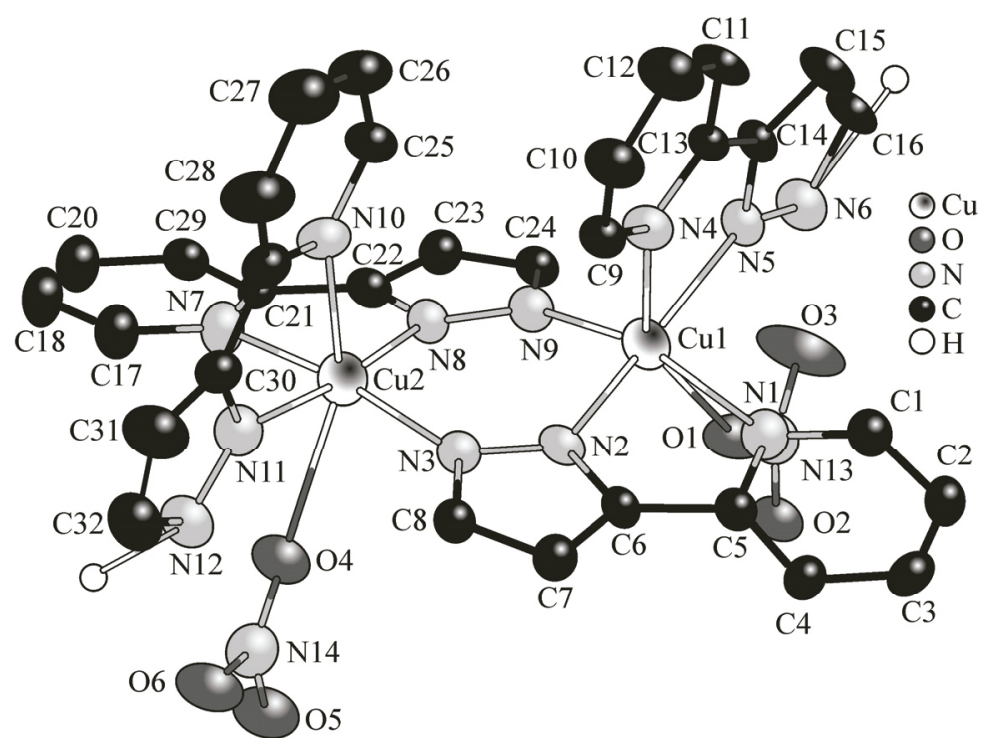

Fig. 2. Coordination environment of the $\mathrm{Cu}(\mathrm{II})$ ion in complex 2. All the hydrogen atoms are omitted for clarity (except for the $\mathrm{H}$ atom of the pyrazole NH group) 


\section{REFERENCES}

1. Li M., Liu L., Zhang L. et al. // CrystEngComm. - 2014. - 16. - P. 6408 - 6416.

2. Cui G.H., He C.H., Jiao C.H. et al. // CrystEngComm. - 2012. - 14. - P. 4210 - 4216.

3. Wang X., Luan J., Lin H. et al. // Dalton Trans. - 2013. - 42. - P. 8375 - 8386.

4. Liu J., Chen L., Cui H. et al. // Chem. Soc. Rev. - 2014. - 43. - P. 6011 - 6061.

5. Aakeröy C.B., Champness N.R., Janiak C. et al. // CrystEngComm. - 2010, - 12. - P. 22 - 43.

6. Yang R., Van Hecke K., Yu B.Y. et al. // Transit Met. Chem. - 2014. - 39. - P. 535 - 541.

7. Hao J.M., Zhao Y.N., Yang R. et al. // J. Mol. Struct. - 2014. - 1070. - P. 58 - 64.

8. Zou R.Q., Liu C.S., Huang Z. et al. // Cryst. Growth Des. - 2006. - 6. - P. $99-108$.

9. Li J.R., Bu X.H. // Eur. J. Inorg. Chem. - 2008. - 2008. - P. 27 - 40.

10. Du X., Wang Y.Y., Zhao Y.Q. et al. // J. Struct. Chem. - 2014. - 55. - P. $734-738$.

11. Wang X.X., Yu B.Y., Van Hecke K. et al. // RSC Adv. - 2014. - 4. - P. 61281 - 61289.

12. Arroyo M., Gomez-Iglesias P., Anton N. et al. // Dalton Trans. - 2014. - 43. - P. 4009 - 4020.

13. Hu T.L., Zou R.Q., Li J.R. et al. // Dalton Trans. - 2008. - 10. - P. 1302 - 1311.

14. Zhang X., Wei P., Sun D. et al. // Cryst. Growth Des. - 2009. - 9. - P. $4424-4428$.

15. Liu C.S., Li J.R., Zou R.Q. et al. // J. Mol. Struct. - 2007. - 843. - P. 66 - 77.

16. Uber J.S., Mutikainen I., Turpeinen U. et al. // Inorg. Chem. Commun. - 2007. - 10. - P. 1478 - 1481.

17. Arroyo M., Miguel D., Villafane F. et al. // Dalton Trans. - 2012. - 41. - P. 7017 - 7025.

18. Wang F., Schwabacher A.W. // Tetrahedron Lett. - 1999. - 40. - P. 4779 - 4782.

19. Sheldrick G.M. SADABS, Program for empirical absorption correction of area detector data, Univ. Göttingen, Germany, 1996.

20. Sheldrick G.M. SHELXS-97, University of Göttingen, Göttingen, Germany, 1997.

21. Sheldrick G.M. SHELXL-97, University of Göttingen, Göttingen, Germany, 1997.

22. Spek A.L. PLATON, A Multipurpose Crystallographic Tool, Utrecht University, Utrecht, 2000.

23. Hu T.L., Li J.R., Liu C.S. et al. // Inorg. Chem. - 2006. - 45. - P. 162 - 173.

24. Addison A.W., Rao T.N., Reedijk J. et al. // J. Chem. Soc., Dalton Trans. - 1984. - 7. - P. $1349-1356$.

25. Mann K.V., Jeffery J., Rees L. et al. // J. Chem. Soc., Dalton Trans. - 1999. - 3. - P. 339 - 348.

26. Pons J., López X., Benet E. et al. // Polyhedron. - 1990. - 9. - P. 2839 - 2845. 